\title{
Filter paper blood samples used in serological studies of respiratory virus infections in children
}

\author{
S. M. K. CHISHTY \\ From the Department of Microbiology, University of Karachi, Pakistan
}

SYNOPSIS Filter paper blood samples were used to measure complement-fixation antibody in 34 children with sore throats. The method was satisfactory and should be particularly useful to minimize trauma in general practice and to conserve reagents in developing countries.

Blood samples collected on filter paper have been used for the measurement of poliovirus antibodies (Kalter, 1957; Green and Opton, 1960), adenovirus and measles antibodies (Brody, McAlister, Haseley, and Lee, 1964), certain respiratory viruses (Chin, Schmidt, Lennette, and Hanahoe, 1966), and rubella antibodies (Draper and Kelly, 1969). The present paper describes the use of such samples in an investigation of sore throats in young children in a general practice. The slightly lower antibody titre obtained from these samples was also investigated.

\section{Material and Methods}

\section{COLLECTION AND TREATMENT OF BLOOD} SAM PLES

Strips of filter paper (Whatman no. 1) $7 \mathrm{~mm}$ wide were soaked in blood obtained by the finger-prick method and were placed in plain plastic tubes. On reaching the laboratory the stoppers were removed from the tubes which were left in the laboratory drawer to let the blood dry at room temperature. After drying, a length of filter paper equivalent to that soaked by $0.04 \mathrm{ml}$ of whole blood was cut into minute pieces and placed in a syringe containing $0.64 \mathrm{ml}$ of veronal-buffered saline. The needle end of the syringe was stoppered by a plastic device and the top covered with an adhesive label. The syringes were then kept at $4^{\circ} \mathrm{C}$ overnight. After soaking the eluate was forced out into test tubes and was inactivated at $56^{\circ} \mathrm{C}$ for 30 minutes. The liquid was then centrifuged for one hour at 2,100 rpm and the supernatant was used as the initial 1:16 dilution of the 'serum'.

\section{COMPLEMENT FIXATION TEST}

The method described by Bradstreet and Taylor (1962) was employed using $2 \frac{1}{2} \mathbf{M H D}_{50}$ of complement.

Received for publication 9 June 1970.
For the microtechnique, the Takatsy 'microtitration' unit was used with Linbro disposable trays (I.S. MRC-96) and volumes of $0.025 \mathrm{ml}$. When macrotechniques were used for confirmation and comparison WHO plates and $0.1 \mathrm{ml}$ volumes were used. Acute and convalescent sera were tested for antibodies to the following antigens: influenza A, B, and C, Sendai, adenovirus, respiratory syncytial virus, and herpes simplex virus. All reagents except the herpes simplex antigen were obtained from the Standards Laboratory for Serological Reagents, Central Public Health Laboratory, Colindale, London. The herpes simplex antigen was prepared in the Wellcome Laboratory, City Hospital, Edinburgh.

TREATMENT OF SERUM WITH

2-MERCAPTOETHANOL

Equal volumes of $1: 8$ dilutions of serum and 0.05 M-mercaptoethanol (Anderson, Jennes, Brumfield, and Gough, 1964) were kept in stoppered test tubes for 24 hours. The contents were then transferred into $8 / 32$ in. dialysis tubing and dialysed for 48 hours in frequent changes of veronal-buffered saline. After dialysis these 1:16 dilutions were kept at $+4^{\circ} \mathrm{C}$ until complement-fixation tests were performed. A second portion of $1: 8$ diluted serum was treated with veronal-buffered saline alone as a control.

\section{Results}

Complement-fixation tests were carried out on the acute and convalescent blood specimens from 34 children with sore throats. Eleven children (32\%) showed a fourfold or greater increase in antibody titre against one or more viruses whereas the isolation rate from throat swabs was only $2.9 \%$ in these patients. The results are shown in Table I. It will be seen that most of the antibody titres measured 
by this method are low, suggesting that there is a general mechanical retention of the blood on the filter paper or that the larger $19 \mathrm{~S}$ molecules adhere to the paper pulp.

To investigate the possible reasons for these low titres, rabbits were immunized to provide an adequate supply of blood. Complement-fixation tests were carried out on the blood from the six rabbits using the microtechnique for serum and filter paper samples and the macrotechnique for serum samples. The results are shown in Table II and confirm that a lower titre is usually obtained from dried blood samples using the microtechnique than from serum samples.

In an attempt to investigate the loss of titre, rabbit serum samples were treated with 2-mercaptoethanol. Complement-fixation tests were carried out and the titres were compared with those obtained from untreated serum and filter paper blood samples. The results shown in Table III demonstrate the effect of 2 mercaptoethanol on the IgM fraction depending on the immunization schedule and route of inoculation. There is, however, no relationship between the removal of IgM by 2-mercaptoethanol and the reduction in titre of the filter paper samples. This result suggests that the loss of titre is not due to inactivation or specific mechanical adherence of the $19 \mathrm{~S}$ antibody by the filter paper. In immunoelectrophoresis studies a weaker line was produced by the blood eluate confirming this suggestion.

\begin{tabular}{|c|c|c|c|c|c|c|c|c|}
\hline Case No. & $\begin{array}{l}\text { Serum } \\
\text { Sample }\end{array}$ & $\underset{A}{\text { Influenza }}$ & $\begin{array}{l}\text { Influenza } \\
B\end{array}$ & $\underset{C}{\text { Influenza }}$ & Sendai & Adenovirus & $\begin{array}{l}\text { Respiratory } \\
\text { Syncytial } \\
\text { Virus }\end{array}$ & Herpes Simplex \\
\hline \multirow[t]{2}{*}{1} & Acute & -1 & - & - & - & - & 一 & - \\
\hline & Convalescent & - & - & - & 32 & 16 & - & 一 \\
\hline \multirow[t]{2}{*}{2} & Acute & 16 & 16 & - & - & - & - & - \\
\hline & Convalescent & 16 & 16 & - & - & - & - & 16 \\
\hline \multirow[t]{2}{*}{3} & Acute & - & - & - & - & - & - & - \\
\hline & Convalescent & - & 一 & 16 & 32 & 16 & 32 & 32 \\
\hline \multirow[t]{2}{*}{4} & Acute & - & - & - & - & - & - & 16 \\
\hline & Convalescent & - & 16 & 16 & - & - & - & 64 \\
\hline \multirow[t]{2}{*}{5} & Acute & - & - & - & - & - & - & - \\
\hline & Convalescent & - & - & 32 & - & - & - & - \\
\hline \multirow[t]{2}{*}{6} & Acute & - & 一 & - & 16 & - & - & - \\
\hline & Convalescent & - & - & 16 & 16 & 32 & - & - \\
\hline \multirow[t]{2}{*}{7} & Acute & - & - & - & - & - & - & - \\
\hline & Convalescent & - & - & - & - & - & - & 128 \\
\hline \multirow[t]{2}{*}{8} & Acute & 16 & - & 一 & 16 & - & - & - \\
\hline & Convalescent & 16 & - & - & 16 & 32 & - & - \\
\hline \multirow[t]{2}{*}{9} & Acute & - & 一 & - & - & $\overline{-}$ & 一 & - \\
\hline & Convalescent & - & - & 32 & - & 16 & - & - \\
\hline \multirow[t]{2}{*}{10} & Acute & - & - & - & - & - & - & - \\
\hline & Convalescent & - & 64 & - & - & - & 16 & $\overline{0}$ \\
\hline \multirow{2}{*}{11} & Acute & 16 & - & 16 & - & - & - & 32 \\
\hline & Convalescent & 16 & 16 & 16 & 16 & 32 & - & 16 \\
\hline
\end{tabular}

Table I Results of micro-complement fixation tests on filter paper eluates of blood from patients with sore throats $1-=<16$.

\begin{tabular}{|c|c|c|c|c|c|c|c|c|c|c|c|}
\hline \multirow[t]{3}{*}{ Rabbit } & \multicolumn{2}{|l|}{ Inoculum } & \multirow[t]{3}{*}{ Route } & \multirow[t]{3}{*}{ Rabbit } & \multirow{3}{*}{$\begin{array}{l}\text { Day } \\
\text { after } \\
\text { Inocu- } \\
\text { lation }\end{array}$} & \multicolumn{6}{|c|}{ Type of Sample } \\
\hline & \multirow[t]{2}{*}{ Day 1} & \multirow[t]{2}{*}{ Day 80} & & & & \multicolumn{2}{|c|}{ Blood Eluate } & \multicolumn{2}{|c|}{ Serum (Micro) } & \multicolumn{2}{|c|}{ Serum (Macro) } \\
\hline & & & & & & Flu $A$ & Flu B & Flu $A$ & $F / u B$ & Flu $A$ & Flu B \\
\hline \multirow[t]{2}{*}{$1 \& 2$} & \multirow{3}{*}{$\begin{array}{l}\text { Influenza vaccine } \\
A_{2} \text { Neth/BJh } \\
\text { plus adjuvant } \\
0.5 \mathrm{ml} \\
\text { As above } \\
\text { No adjuvant }\end{array}$} & \multirow{2}{*}{$\begin{array}{l}\text { As before } \\
0.2 \mathrm{ml}\end{array}$} & \multirow[t]{2}{*}{ Intradermal } & 1 & 92 & 128 & 64 & 512 & 128 & 512 & 128 \\
\hline & & & & 2 & 92 & 128 & 32 & 256 & 128 & 128 & 128 \\
\hline $3 \& 4$ & & Nil & Intradermal & $\begin{array}{l}3 \\
4\end{array}$ & $\begin{array}{l}92 \\
88\end{array}$ & \multirow{2}{*}{\multicolumn{2}{|c|}{\begin{tabular}{lc}
128 & 256 \\
128 & 128 \\
Herpes & Simplex \\
\multicolumn{2}{c}{128} \\
\multicolumn{2}{c}{256}
\end{tabular}}} & \multirow{2}{*}{\multicolumn{2}{|c|}{\begin{tabular}{lc}
512 & 256 \\
128 & 64 \\
Herpes & Simplex \\
\multicolumn{2}{c}{512} \\
512
\end{tabular}}} & \multirow{2}{*}{$\begin{array}{l}256 \\
128 \\
\text { Herpe }\end{array}$} & $\begin{array}{l}256 \\
128 \\
\text { Simplex }\end{array}$ \\
\hline $5 \& 6$ & Herpes simplex & Nil & Intracorneal & $\begin{array}{l}5 \\
6\end{array}$ & $\begin{array}{l}92 \\
92\end{array}$ & & & & & & \\
\hline
\end{tabular}

Table II Results of complement-fixation tests on blood eluate and serum from immunized rabbits using the micro and macro techniques 


\begin{tabular}{|c|c|c|c|c|c|c|c|c|c|c|c|}
\hline \multirow[t]{3}{*}{ Rabbit } & \multicolumn{2}{|l|}{ Inoculum } & \multirow[t]{3}{*}{ Route } & \multirow[t]{3}{*}{ Rabbit } & \multirow{3}{*}{$\begin{array}{l}\text { Day } \\
\text { after } \\
\text { Inocu- } \\
\text { lation }\end{array}$} & \multicolumn{6}{|c|}{ Type of Sample } \\
\hline & \multirow[t]{2}{*}{ Day 1} & \multirow[t]{2}{*}{ Day 80} & & & & \multicolumn{2}{|c|}{ Blood Eluate } & \multicolumn{2}{|l|}{ Serum } & \multicolumn{2}{|c|}{$\begin{array}{l}\text { Mercaptoethanol- } \\
\text { treated Serum }\end{array}$} \\
\hline & & & & & & Flu $A$ & Flu B & Flu $A$ & Flu $B$ & Flu $A$ & Flu $B$ \\
\hline $1 \& 2$ & $\begin{array}{l}\text { Influenza vaccine } \\
\mathbf{A}_{2} \text { Neth } B / \mathrm{Jh} \\
\text { plus adjuvant } \\
0.5 \mathrm{ml} \\
\text { As above }\end{array}$ & $\begin{array}{l}\text { As before } \\
0.2 \mathrm{ml}\end{array}$ & Intradermal & $\begin{array}{l}1 \\
2\end{array}$ & $\begin{array}{r}0 \\
92 \\
0 \\
92 \\
0\end{array}$ & $\begin{array}{r}<16 \\
128 \\
32 \\
128 \\
<16\end{array}$ & $\begin{array}{r}<16 \\
64 \\
<16 \\
32 \\
<16\end{array}$ & $\begin{array}{r}32 \\
512 \\
32 \\
256 \\
<16\end{array}$ & $\begin{array}{r}16 \\
128 \\
16 \\
128 \\
<16\end{array}$ & $\begin{array}{r}16 \\
16 \\
16 \\
16 \\
<16\end{array}$ & $\begin{array}{r}16 \\
32 \\
16 \\
16 \\
<16\end{array}$ \\
\hline $2 \propto 4$ & No adjuvant & Nil & Intradermal & 4 & $\begin{array}{r}92 \\
0 \\
88\end{array}$ & $\begin{array}{c}128 \\
64 \\
128 \\
\text { Herpes. }\end{array}$ & $\begin{array}{c}256 \\
64 \\
128 \\
\text { implex }\end{array}$ & $\begin{array}{l}512 \\
128 \\
128 \\
\text { Herpes }\end{array}$ & $\begin{array}{r}256 \\
64 \\
64 \\
\text { simplex }\end{array}$ & $\begin{array}{c}64 \\
128 \\
64 \\
\text { Herpes }\end{array}$ & $\begin{array}{c}64 \\
64 \\
16 \\
\text { simplex }\end{array}$ \\
\hline $5 \& 6$ & Herpes simplex & Nil & Intracorneal & $\begin{array}{l}5 \\
6\end{array}$ & $\begin{array}{r}0 \\
92 \\
0 \\
92\end{array}$ & $\begin{array}{r}1 \\
12 \\
6 \\
25\end{array}$ & & $\begin{array}{l}5 \\
1 \\
5\end{array}$ & $\begin{array}{l}2 \\
2 \\
8 \\
2\end{array}$ & $\begin{array}{l}2 \\
2\end{array}$ & $\begin{array}{l}6 \\
6 \\
4 \\
6\end{array}$ \\
\hline
\end{tabular}

Table III Results of complement-fixation tests on blood eluate, serum, and mercaptoethanol-treated serum from immunized rabbits using the microtechnique

\section{Discussion}

Serological evidence for viral infection is essential in aetiological studies. This is often difficult to obtain if venepuncture is used, particularly in children in general practice. The present findings show that by using filter paper blood samples and the micro complement-fixation test antibody rises can be detected with a great saving of time, trauma, and materials.

The slight loss of antibody titre in filter paper blood samples previously observed by Brody et al (1964) does not appear to be directly related to adherence of the $19 \mathrm{~S}$ molecules to the paper. It is rather a loss of material due to handling or general mechanical adherence of serum proteins to the filter paper. In a recent paper Cohen, Hatji, and Wisserman (1969) reported the different stability of the immunoglobulin subclasses when stored on filter paper at different temperatures; this must be considered in any serological study using such blood samples.

Besides the value of the method in seroepidemiological surveys the method should be of use in developing countries where reagents are scarce.

This work was carried out in the Wellcome Laboratory, City Hospital, Edinburgh, under the super- vision of Dr Margaret Moffat. I am very grateful to Dr J. D. E. Knox who collected the specimens from his patients and to Dr Angus Stewart who gave considerable advice on the immunoelectrophoresis experiments. Professor Robert Cruickshank and Dr R. H. A. Swain also gave me help and encouragement.

\section{References}

Anderson, R. K., Jenness, R., Brumfield, H. P., and Gough, P. (1964). Brucella-agglutinating antibodies: relation of mercaptoethanol stability to complement fixation. Science, 143, 1334-1335.

Bradstreet, C. M. P., and Taylor, C. E. D. (1962). Technique of complement-fixation test applicable to the diagnosis of virus diseases. Mth. Bull. Minist. Hlth Lab. Serv., 21, 96-104.

Brody, J. A., McAlister, R., Haseley, R., and Lee, P. (1964). Use of dried whole blood collected on filter paper disks in adenovirus complement fixation and measles hemagglutination inhibition tests. J. Immunol., 92, 854-857.

Chin, J., Schimdt, N. J., Lennette, E. H., and Hanahoe, M. (1966). Filter paper disc method of collecting whole blood for serologic studies in children. Amer. J. Epidem., 84, 74-80.

Cohen, A. B., Hatgi, J. N., and Wisseman, C. L., Jr. (1969). Storage stability of different antibody species against arbovirus and rickettsial antigens in blood dried on filter paper discs. Amer. J. Epidem., 89, 345-352.

Draper, C. C., and Kelly, A. (1969). Haemagglutination-inhibition tests for rubella. Brit. med. J., 1, 177-178.

Green, R. H., and Opton, E. M. (1960). A micromethod for determination of poliovirus antibody suitable for mass surveys. Amer. J. Hyg., 72, 195-203.

Kalter, S. S. (1957). A disc method for titration and neutralization of poliovirus. (Abstr.). Fed. Proc., 16, 419. 